\title{
Sedimentology and magnetic susceptibility of Mississippian (Tournaisian) carbonate sections in Belgium
}

\author{
CApucine Bertola, Frédéric Boulvain, AnNe-Christine DA Silva \& Eddy Poty
}

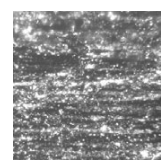

\begin{abstract}
Magnetic susceptibility (MS) and biostratigraphy have been used to correlate better the reference sections of the Belgian Tournaisian, the Rivage road and railway sections and the Gendron-Celles railway section. These $200 \mathrm{~m}$ thick time-equivalent sections are about sixty kilometres apart and belong to two different sedimentation areas: a shallow ramp setting for Rivage (Condroz Sedimentation Area) and a subsiding area for Gendron (Dinant Sedimentation Area). The sedimentological model shows that both sections are characterized by a carbonate-dominated sedimentation (crinoids-peloids-algae assemblages), interrupted by more argillaceous facies related to rapid sea-level rises (crinoids-brachiopods-bryozoans assemblages). Accommodation space was significantly higher in the DSA and allowed the development of Waulsortian buildups during the Ivorian. Variations of magnetic susceptibility (MS) seem to be related to fluctuations in detrital input and carbonate productivity. MS evolution with palaeogeography can be integrated in the previously published model for the Devonian ramp system: external ramp settings have low carbonate productivity, low water agitation and high MS, whereas more proximal environments are characterized by higher carbonate productivity, higher water agitation and lower MS. MS curves are in general agreements with the $3^{\text {rd }}$-order sequence interpretation. Lowstand system tracts (LST) show the highest MS values while transgressive system tracts (TST) are characterized by decreasing values and highstand system tracts/falling stage system tracts (HST/FSST) by the lowest values. $•$ Key words: magnetic susceptibility, Mississippian, limestone, facies, ramp, Belgium.
\end{abstract}

Bertola, C., Boulvain, F., DA Silva, A.-C. \& Poty, E. 2013. Sedimentology and magnetic susceptibility of Mississippian (Tournaisian) carbonate sections in Belgium. Bulletin of Geosciences 88(1), 69-82 (11 figures). Czech Geological Survey, Prague. ISSN 1214-1119. Manuscript received February 2, 2012; accepted in revised form July 10, 2012; published online October 29, 2012; issued December 6, 2012.

Capucine Bertola, Frédéric Boulvain (corresponding author) \& Anne-Christine Da Silva, Pétrologie sédimentaire, B20, Université de Liège, B-4000 Liège, Belgium; fboulvain@ulg.ac.be•Eddy Poty, Paléontologie animale et humaine, B18, Université de Liège, B-4000 Liège, Belgium

Changes in magnetic susceptibility (MS) of sedimentary successions are considered to be related to sea level variations (Devleeschouwer 1999, Ellwood et al. 1999). This inferred relationship led to the proposal to use MS for high-resolution global correlation of marine sedimentary rocks (e.g. Crick et al. 1997). The major influence of sea level on the MS signal is related to the strong link between MS and detrital components and the assumption that the detrital input is generally controlled by eustasy (Crick et al. 2001). In this way, a sea-level fall increases the proportion of exposed continental area, increases erosion and leads to higher MS values, whereas rising sea level decreases MS (Crick et al. 2001). However, climatic variations influence MS through changes in rainfall (high rainfall increases erosion and MS), glacial-interglacial periods (glacial periods involve glacial erosion and marine regression and both effects increase MS) and pedogenesis (formation of magnetic minerals in soils: Crick et al. 2001).
In addition to subaqueous delivery, different authors considered that magnetic minerals in carbonate sediments could also be supplied from aeolian suspension and atmospheric dust (Hladil 2002; Hladil et al. 2006, 2010). Furthermore, early and late diagenesis can be responsible for MS variation through mineralogical transformations, dissolution or authigenesis (Rochette 1987, McCabe \& Elmore 1989, Zegers et al. 2003).

A few studies proposed a link between MS and depositional environment (Borradaile et al. 1993, Da Silva \& Boulvain 2006, Da Silva et al. 2009a, b). These studies presented different MS/depositional environment responses in different platform types, suggesting that sealevel changes leading to variation in detrital input are not the only parameter controlling average MS values. Other primary or secondary processes probably also influenced magnetic mineral distribution. Primary processes such as water agitation and carbonate production during deposition 


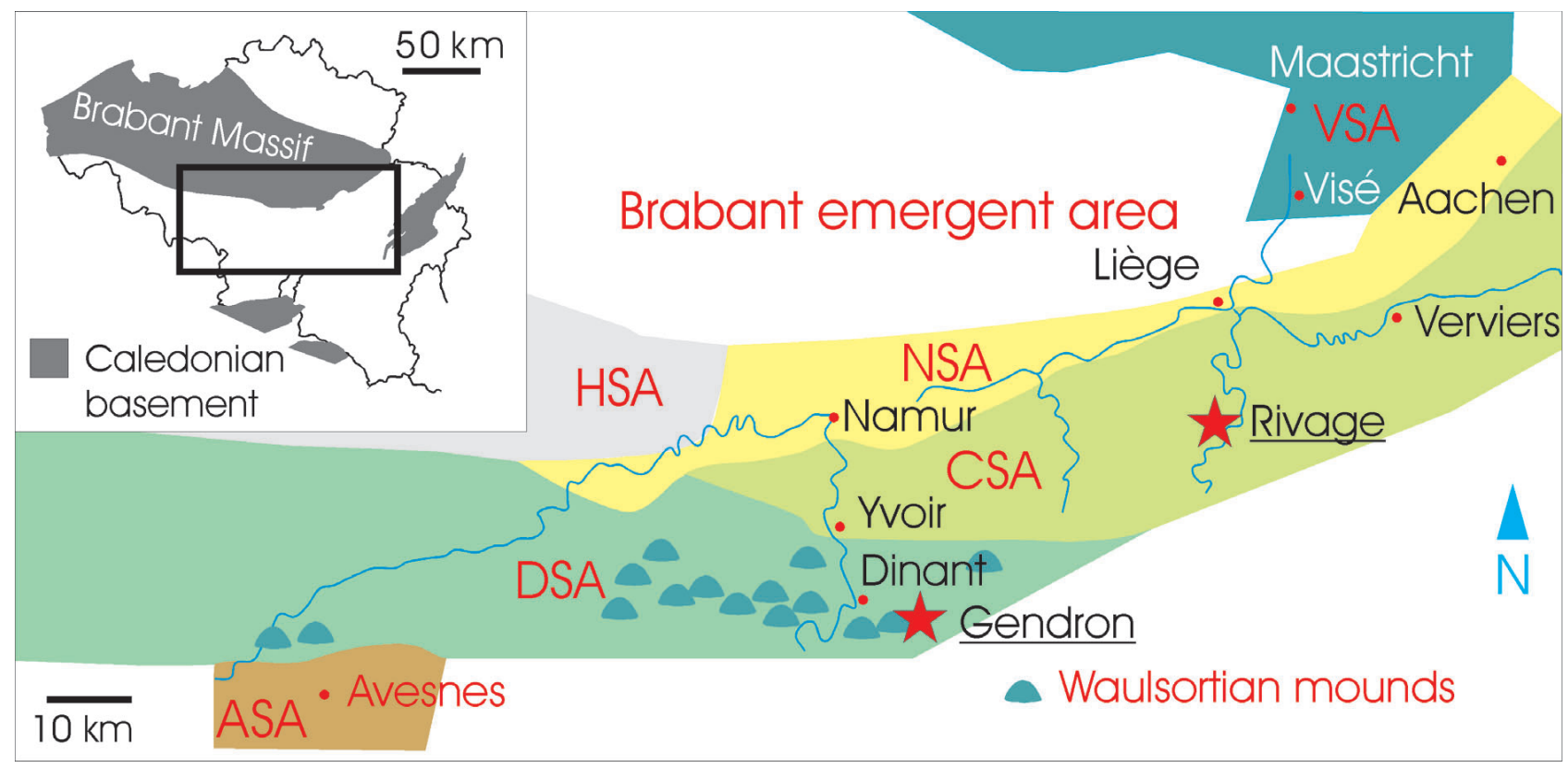

Figure 1. Sedimentation areas for the Tournaisian of Belgium, with location of the studied sections. Abbreviations: VSA - Visé Sedimentation Area; NSA - Namur Sedimentation Area; HAS - Hainaut Sedimentation Area; CSA - Condroz Sedimentation Area; DSA - Dinant Sedimentation Area; ASA - Avesnes Sedimentation Area. After Hance et al. (2001). Location of studied sections Gendron and Rivage indicated.

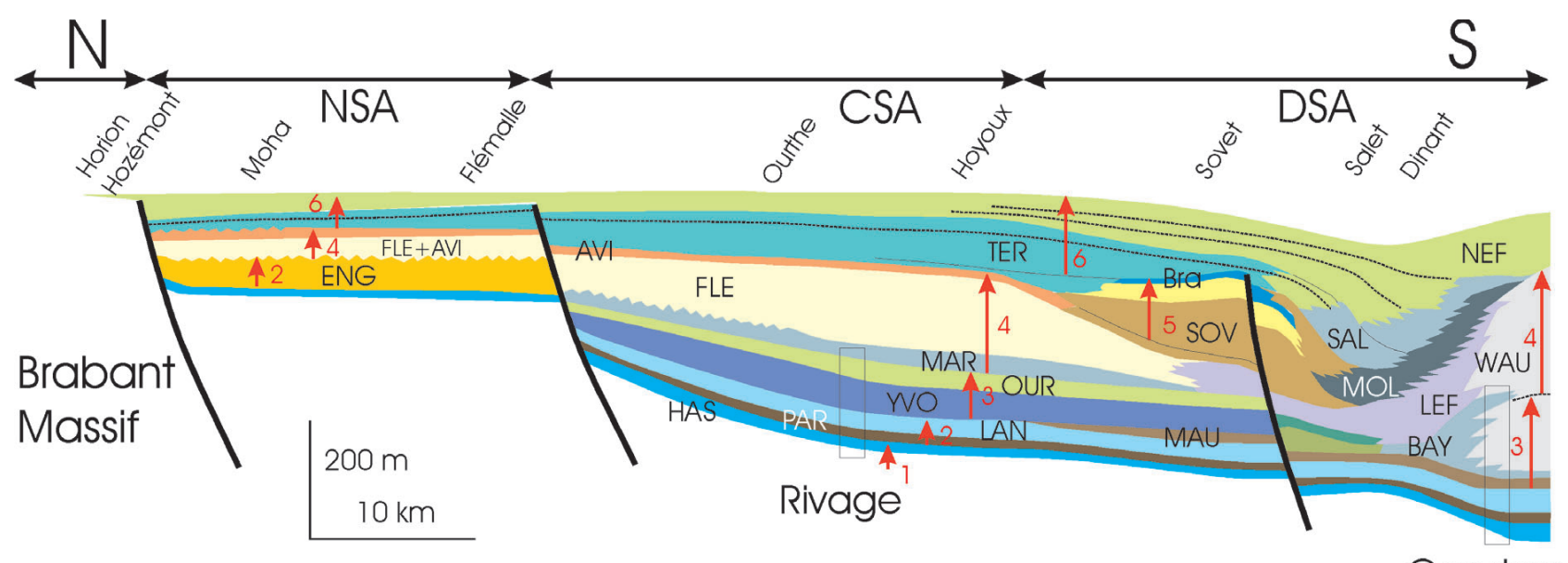

Figure 2. Schematic cross-section in the Tournaisian sedimentary basin, with sedimentary sequences (1-6) and location of the Rivage and Gendron sections. Abbreviations: HAS - Hastière Fm.; PAR - Pont d'Arcole Fm.; LAN - Landelies Fm.; MAU - Maurenne Fm.; YVO - Yvoir Fm.; OUR - Ourthe Fm.; MAR - Martinrive Fm.; BAY - Bayard Fm.; WAU - Waulsort Fm.; LEF - Leffe Fm. After Hance et al. (2001).

seem to be important factors (Da Silva et al. 2009b, Bábek et al. 2010).

MS studies on Tournaisian successions in the world are relatively uncommon, by comparison with general stratigraphic and sedimentological studies. Zhang et al. (2000) published a study comparing the MS evolution with sea level variations for Tournaisian platform limestones from the Guizhou province in China. A very detailed study of the MS evolution and its link with paleoenvironments by Bábek et al. (2010) focused on sections encompassing the TournaisianViséan boundary in Ireland, England, Belgium and Germany.
The aim of this paper is to apply magnetic susceptibility studies to the thick Belgian Mississippian (Tournaisian) limestone successions. In the general context outlined above, the main goals of this paper are as follow: (1) to test the reliability of the correlations obtained with MS techniques on large scale successions in different settings; (2) to identify the link between MS, environmental parameters and sequence stratigraphy; and (3) to test the impact of parameters such as water agitation during deposition and carbonate production in a ramp setting, where these parameters have important impacts on the sedimentation. 


\section{Methods}

The MS measurements were made on a KLY-3 Kappabridge device ( $c f$. Da Silva \& Boulvain 2006). Three measurements were made on each sample weighed with a precision of $0.01 \mathrm{~g}$. The sampling interval for the MS curves is around $1 \mathrm{~m}$. To identify some of the MS carriers, calcareous shale from the Pont d'Arcole Formation (Rivage section) was crushed, and treated with $0.1 \mathrm{M}$ acetic acid.

Petrographic analysis comes from the detailed bed-bybed study of outcrops and careful observation of 450 thin sections. Microfacies were defined according to textures, sedimentary structures and fossil assemblages. The textural classification used to characterise microfacies follows Dunham (1962). Microfacies were reported along a ramp profile with three main facies belts: outer ramp, mid ramp and inner ramp (Read 1985, Burchette \& Wright 1992).

\section{Geological setting}

The Early Carboniferous of Southern Belgium belongs to the Rhenish Variscan fold and thrust belt (Fielitz \& Mansy 1999). During the Early Carboniferous, the sedimentary context corresponds to a carbonate ramp, with a prominent North-South bathymetric gradient, the more proximal environments and the less complete successions developing northwards.

The Early Carboniferous sedimentation south of the London-Brabant Massif was related to an extensional regime. Common thickness variations of the deposits were the result of normal synsedimentary faulting (Poty 1997). This synsedimentary faulting was responsible for different accommodation rates and for lateral differentiation in sedimentation areas showing different lithostratigraphy and sedimentological evolution through time (Fig. 1) (Poty 1997). This work focuses on two sedimentation areas, the Condroz Sedimentation Area (CSA) and the Dinant Sedimentation Area (DSA) (Figs 1, 2).

The CSA is characterized by relatively proximal facies, interrupted eastwards by sedimentary hiatuses, but becoming more continuous towards the SW. The DSA (equivalent to the "Auge dinantaise", Paproth et al. 1983) records deeper and more continuous series, locally influenced by the development of Waulsortian mounds during the upper part of the Tournaisian (Lees et al. 1985, Lees 1997; Fig. 2).

The Early Carboniferous sedimentation in Belgium is also constrained by sea-level variations, recorded in $3^{\text {rd }}$ order sequences, as proposed by Hance et al. (2001). These sequences are integrated in an overall transgressive cycle, covering progressively the shores of the London-Brabant Massif and dramatically shifting facies belts towards the North.

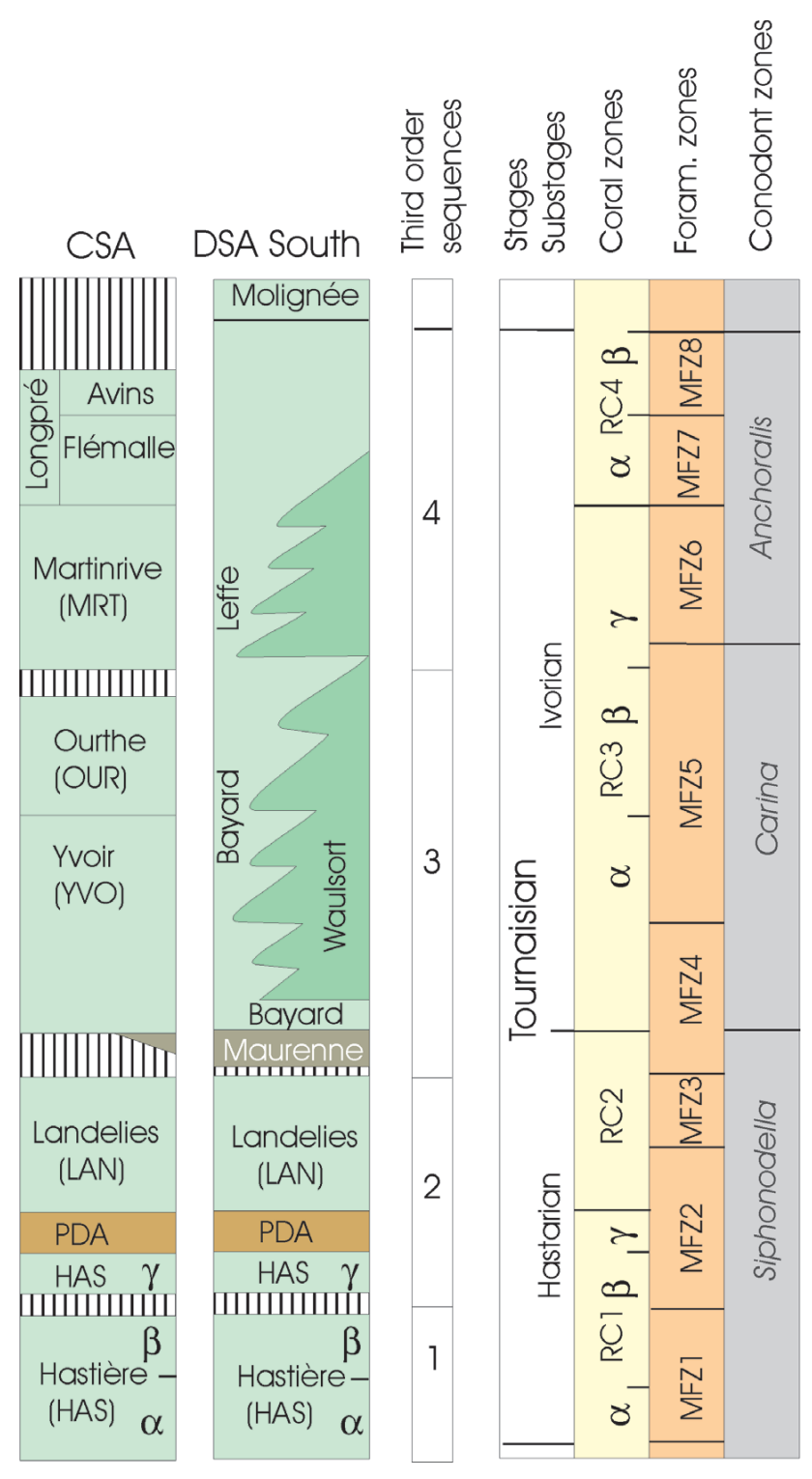

Figure 3. Lithostratigraphy, biostratigraphy and sequence stratigraphy of the DSA and CSA sedimentation areas. After Poty et al. (2006, 2011).

A complete bio- and lithostratigraphical scale for the Tournaisian-Viséan of Belgium was published by Paproth et al. (1983). Recent developments in biostratigraphy and application of sequence stratigraphy allowed Hance et al. (2001) and Poty et al. $(2001,2006,2011)$ to propose an improved stratigraphic canvas for the Tournaisian of the DSA and CSA (Fig. 3). The base of the Carboniferous (Tournaisian) is defined at the first appearance of the conodont Siphonodella sulcata. As the taxon has not been discovered in Belgium, the base of the Tournaisian is still not precisely defined in the studied sections, but is possibly situated close to the base of the Hastière Formation.

Poty (1985) described four coral zones (RC1-RC4) in the Tournaisian. Foraminifera were first studied by Conil et al. (1977) and revised by Hance (in Poty et al. 2006). 


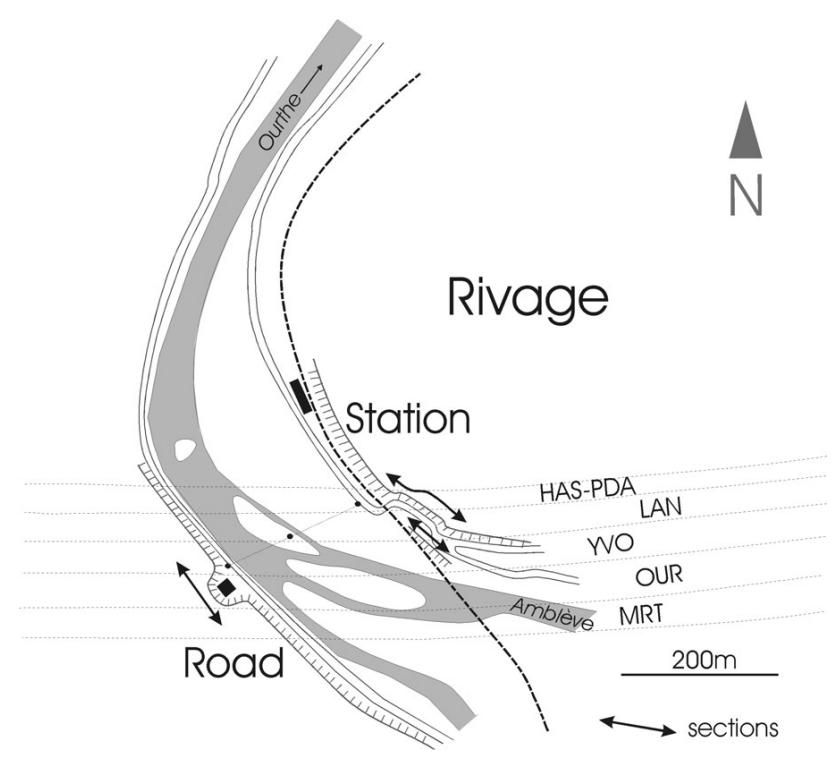

Figure 4. Location of the two parts of the Rivage section. Abbreviations: HAS - Hastière Fm.; PDA - Pont d'Arcole Fm.; YVO - Yvoir Fm.; OUR - Ourthe Fm.; MRT - Martinrive Fm.

This author defined eight foraminifer zones in the Tournaisian (MFZ1-MFZ8). Three conodont zones were recognized by Groessens (1975): Siphonodella, Carina, Anchoralis (Fig. 3).

\section{Lithostratigraphic description of the Gendron and Rivage sections}

In the Ardennes, Variscan tectonism affected the Devonian-Carboniferous platform and most sections are folded and faulted (see Fig. 5B). Two sections (Rivage and Gendron-Celles) were chosen on the basis of their outstanding outcrop quality and different palaeogeographic setting. One of the sections, Rivage, is a composite succession based on two outcrops correlated by the boundary between two lithostratigraphic units (Fig. 4), this boundary corresponding to a major facies change (transition from Landelies to Yvoir formations).

In the two areas (DSA and CSA), sedimentation is dominated by dark grey massive or stratified limestones, with some minor argillaceous beds or seams, and subordinate thicker shales or argillaceous limestone units. The CSA section encompasses the uppermost Famennian Comblain-au-Pont Formation and the Tournaisian Hastière, Pont d'Arcole, Landelies, Yvoir, Ourthe and Martinrive formations. For the DSA Gendron section, the succession corresponds to the uppermost Comblain-au-Pont, Hastière, Pont d'Arcole, Landelies, Maurenne, Bayard and Waulsort formations. The Pont d'Arcole and Maurenne formations are the most argillaceous units and Waulsort Formation corresponds to a carbonate mound (Lees et al. 1985).
Whereas secondary dolomitisation may affect all units in each section, pervasive dolomitisation is mainly observed in the Landelies and Waulsort formations.

\section{Rivage section}

The well-known Rivage section (Conil 1964, Groessens 1975, Conil et al. 1986, Devuyst et al. 2005, Poty et al. 2011 ) is located along the north-eastern border of the Dinant Synclinorium, in the CSA (Figs 1 and 5A). The railway section $\left(\mathrm{N} 85^{\circ} \mathrm{E}-68^{\circ} \mathrm{S}\right.$ to $\left.\mathrm{N} 91^{\circ} \mathrm{E}-71^{\circ} \mathrm{S}\right)$ is complemented by another section situated on the other side of the Ourthe River, along the Esneux-Comblain main road $\left(\mathrm{N} 86^{\circ} \mathrm{E}-70^{\circ} \mathrm{S}\right)$.

The last beds of the Comblain-au-Pont Formation correspond to decimetre-to-metre-thick dark grey crinoidal limestone including beds with lamellar stromatoporoids. The Hastière Formation $(19 \mathrm{~m})$ starts with well-bedded $\mathrm{cm}$ - to $\mathrm{m}$-thick dark grey grainstone-packstone beds showing poor macrofauna, followed by crinoidal limestone and ending with more argillaceous limestone with crinoids, brachiopods and sparse rugose corals. The Pont d'Arcole Formation $(10.7 \mathrm{~m})$ is a greenish grey crinoid and brachiopod-rich (Spiriferina peracuta) shale and argillaceous limestone, with some bryozoans and rugose corals. The Landelies Formation $(27 \mathrm{~m}$ ) starts with relatively argillaceous dm-m-thick grey packstones with crinoids, brachiopods and corals ( $S$. rivagensis and Uralinia sp.) and ends with more massive dolomitic limestone (Royseux beds). The Yvoir Formation corresponds to light grey cherty limestone with crinoids. The upper part of the Yvoir Formation and the next units crop out along the road. The Ourthe Formation (34 m) is a thick-bedded (1-2 m) light grey crinoid-rich limestone and is followed by the Martinrive Formation, a dark grey dm-m-thick argillaceous limestone unit with crinoids, brachiopods and cherts.

\section{Gendron-Celles section}

Gendron-Celles is located in the most distal part of the DSA, in the Dinant Synclinorium (Figs 1 and 5B; Conil 1968, Groessens 1975, Lees et al. 1985, Conil et al. 1988, Van Steenwinkel 1993, Devuyst et al. 2005, Poty et al. 2011). The section $\left(\mathrm{N} 90^{\circ} \mathrm{E}-89^{\circ} \mathrm{N}\right)$ crops out along the Dinant-Bertrix railway, close to the station. Beds are affected by local faults and folds, especially in the vicinity of a Waulsortian mound.

The last beds of the Comblain-au-Pont Formation consist of an alternation of dm-m-thick light grey limestone and subordinate shale with crinoids and brachiopods. The Hastière Formation (24 m) shows firstly grey dm-m-thick 


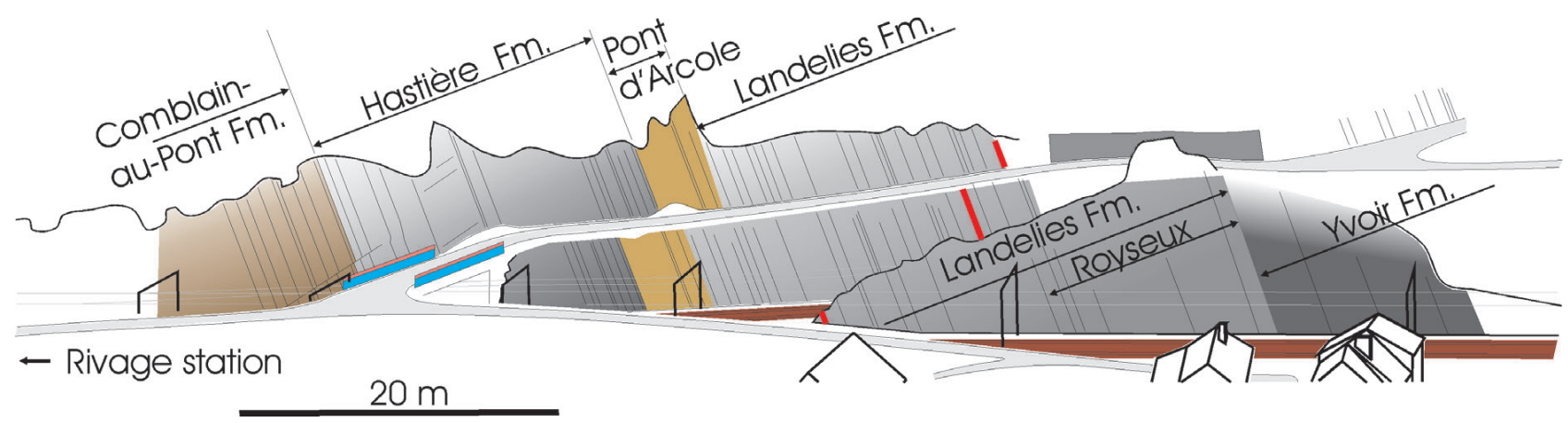

Figure 5A. The Rivage railway section.

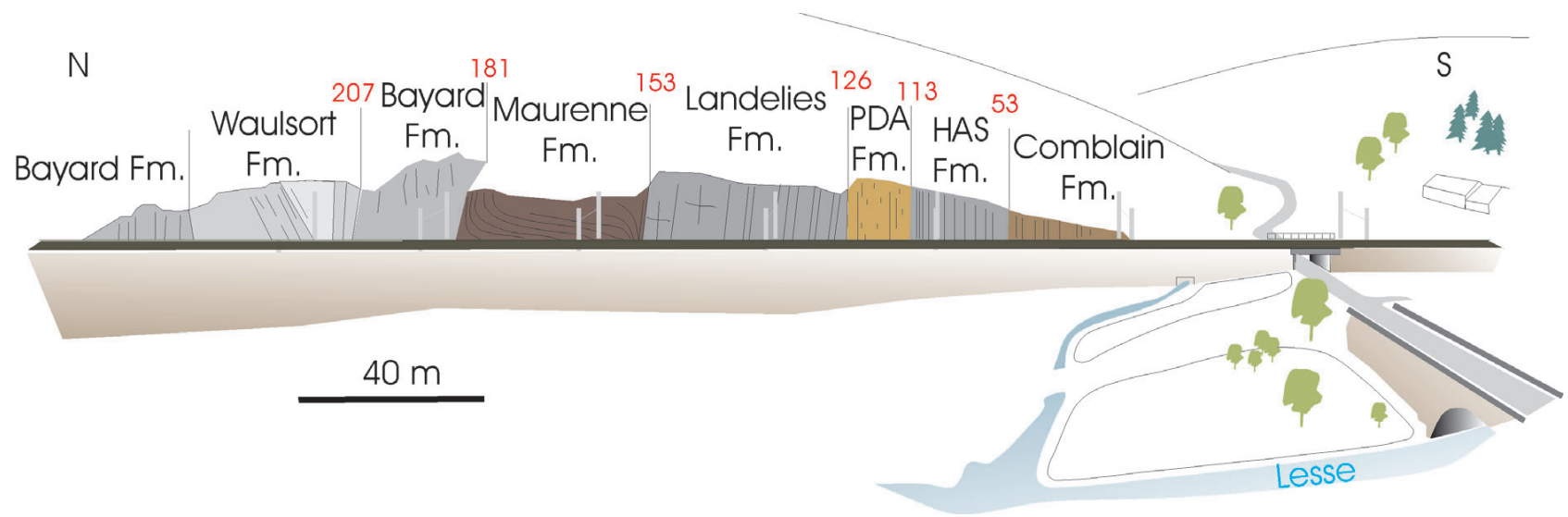

Figure 5B. The Gendron-Celles railway section.

grainstone beds with sparse crinoids and brachiopods, then thicker beds richer in fauna and finally, more argillaceous dm-m-thick dark grey limestone. The shale of the Pont d'Arcole Formation (15 m) contains crinoids, corals, bryozoans and brachiopods and passes progressively upwards to the Landelies Formation (42 m) characterized by light grey well-bedded m-thick grainstone-packstone with crinoids, brachiopods and corals. The Maurenne Formation $(\sim 15 \mathrm{~m})$ is a dark grey $\mathrm{dm}$-thick argillaceous wackestone unit with local storm-generated thin coquina beds. The next two units are interbedded: the Bayard Formation represents the sole and flanks of a Waulsortian mound, whereas the Waulsort Formation corresponds to the mound itself. The Bayard Formation is represented by light grey dm-m-thick crinoid-rich beds with cherts. The Waulsort Formation shows light grey dolomitized wackestone with bryozoans and crinoids.

\section{Description of microfacies}

Microfacies are reported here from the most distal to the most proximal environment. Microfacies are similar in both sections, but slight differences are mentioned where required.

\section{Shale (MF1)}

This facies is constituted by argillaceous, calcareous or dolomitic shale. Rounded and sorted detrital quartz $(0.04-0.1 \mathrm{~mm})$ is locally observed, especially in the Gendron section. Bioturbation is uncommon. Some bioclasts, often partially dissolved, are present. Crinoids, brachiopods and bryozoans are still recognizable. Pyrite crystals are present.

\section{Argillaceous mudstones-wackestones with crinoids and brachiopods (MF2)}

This often nodular limestone is characterized by an argillaceous microsparitic matrix. Some thin sections show alternating argillaceous and carbonate layers with numerous pressure-solution seams. Poorly rounded quartz grains (0.01-0.1 mm) are locally abundant (up to 30\%). Rare horizontal burrows are observed. Bioclasts are often concentrated in thin (mm-thick) graded beds; they are commonly poorly preserved, but some crinoids, brachiopods, ostracods, trilobites, bryozoans, coral fragments, sponge spicules and cyanobacteria (Girvanella sp.) are still recognizable. 


\section{Wackestones-packstones with crinoids and ostracods (MF3)}

These wackestones and packstones with local thin grainstone lenses have a micritic or a microsparitic matrix, often rich in tiny bioclasts. Rounded quartz $(0.01-0.05 \mathrm{~mm})$ grains are locally abundant. Some horizontal and vertical burrows are observed. Bioclasts consist of crinoids, ostracods, bryozoans, gastropods, brachiopods, sponge spicules, trilobites and uncommon foraminifers, calcispherids, Girvanella and palaeosiphonocladales.

\section{Packstones-grainstones with crinoids (MF4)}

Crinoids (mm-cm) are the major constituent of this unit and are associated with other bioclasts such as brachiopods, bryozoans and corals. Grainstones show sparry cement (syntaxial and/or equigranular xenomorphic calcite), and packstones have a micritic or microsparitic matrix.

\section{Packstones-grainstones with peloids and algae (MF5)}

These microsparitic packstone-grainstones include $20-60 \%$ peloids $(0.1-0.4 \mathrm{~mm})$, and poorly preserved crinoids, brachiopods, gastropods, trilobites, ostracods, foraminifers, Girvanella and palaeosiphonocladales. Vertical burrows are observed.

\section{Grainstones with crinoids and peloids (MF6)}

This facies is characterized by relatively well-sorted grainstones with crinoids and rounded peloids $(0.01-0.1 \mathrm{~mm})$. Other bioclasts include palaeosiphonocladales, Girvanella, foraminifers, calcispherids, brachiopods, gastropods and ostracods. Many of the bioclasts are micritized.

\section{Grainstones with crinoids, lithoclasts and peloids (MF7)}

Crinoids, lithoclasts and peloids are the major constituents of this facies. Crinoids are micritized, peloids are rounded or irregular, from 0.1 to $1 \mathrm{~mm}$. Lithoclasts $(\mathrm{mm}-\mathrm{cm})$ are micritic or of algal-microbial origin.

\section{Grainstones with peloids and ooids (MF8)}

Rounded peloids $(\sim 0.2 \mathrm{~mm})$ are abundant. Some lithoclasts are also observed. Most ooids $(\sim 0.4 \mathrm{~mm})$ are bahamites.
Rare partly micritized crinoids, ostracods, brachiopods and bryozoans are seen.

\section{Depositional model}

The microfacies from the Tournaisian of the DSA and CSA show the following characteristics: (1) sedimentation could be assigned to a carbonate-dominated system with subordinate siliciclastic units; (2) there is a continuous facies succession from deep to shallow environments; (3) no barrier reefs were developed; (4) there are no extensive lagoonal or restricted sediments; (5) storm sedimentation is widespread (see below), and (6) there are no slope sediments (slumps, turbidites). These characteristics point to a ramp, rather than a shelf setting (Read 1985, Burchette \& Wright 1992, Herbig \& Weber 1996). Taking this into account, facies can be easily interpreted in the Burchette \& Wright (1992) carbonate ramp model. This model can be applied either to a homoclinal or a distally-steepened ramp (Flügel 2004). The inner ramp is the zone between the shoreline and the fair-weather wave base. The mid-ramp encompasses the zone between the fair-weather wave base and the storm wave base and the outer ramp is located below the normal storm wave base. Most microfacies are carbonate-rich, with full open marine influence marked by the abundance of crinoids and brachiopods. However, supply of detrital silt to sand-sized quartz is locally observed, mainly in Gendron. From MF3 to MF8, the scarcity of lamination or other sedimentary structures is regarded as the result of intense bioturbation (Sepkoski et al. 1991).

The MF1 shale makes up the bulk of the Pont d'Arcole Formation. The fine-grained character of the sediment, lack of bioturbation and rare open-marine fossils suggest a quiet environment, probably locally dysoxic, situated below the storm wave base (Flügel 2004). Facies MF2 occurs sporadically in the Pont d'Arcole Formation and frequently in the Maurenne Formation. This argillaceous limestone was deposited in a quiet environment, below the normal storm wave base. Some bioclasts-rich graded beds correspond to distal storm deposits (Reineck \& Singh 1972, Guillocheau \& Hoffert 1988) that may record exceptional events. MF3 is sporadically represented in nearly all formations. The presence of numerous small transported bioclasts and of minor grainstone levels suggests an environment located close to the storm wave base (Aigner 1985).

An important sedimentological change, corresponding to the transition between outer ramp and mid ramp, is recorded with MF4. This facies is mainly observed in the Ourthe, Bayard and Yvoir formations. It results from the dismantling of crinoid meadows by storms within the storm wave zone (Van Steenwinkel 1980, 1988; Préat \& Kasimi 1995). MF5, mainly observed in the Hastière and 


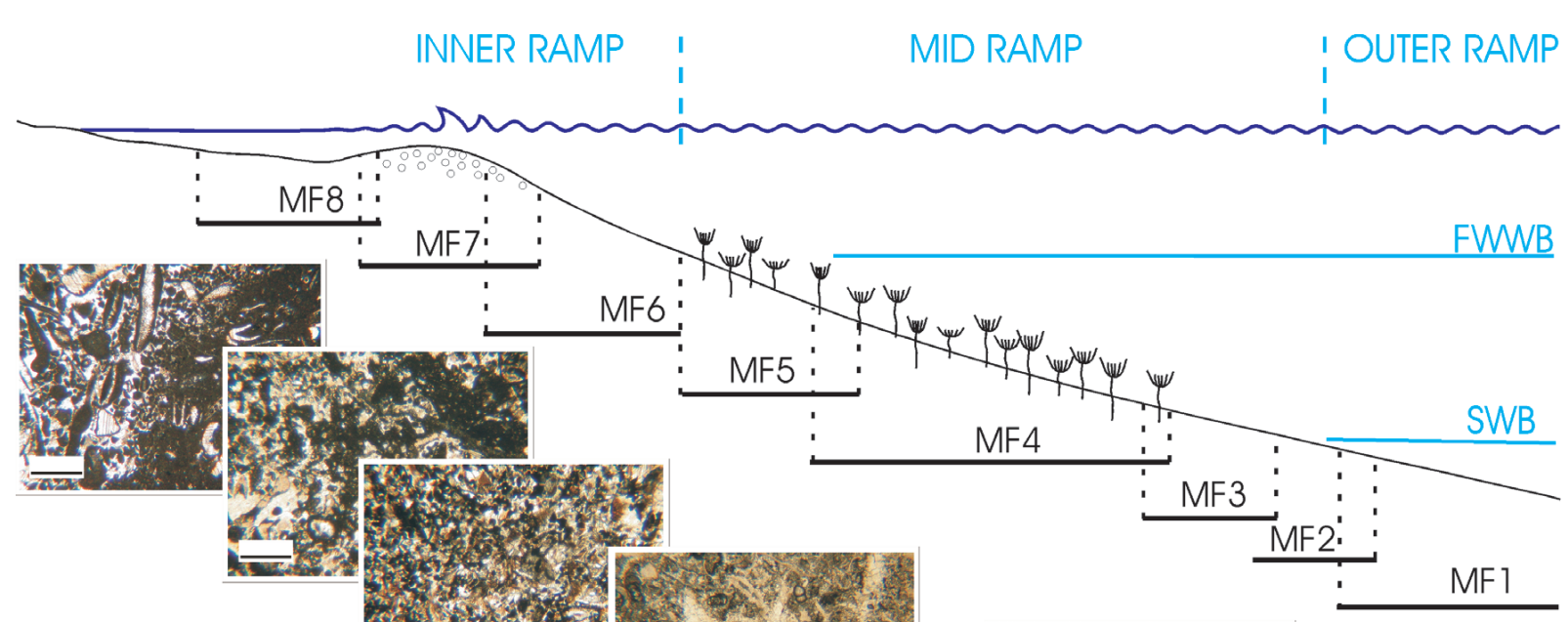

MF2: Argillaceous M/W with crinoids and brachiopods

MF3: P/W with crinoids and ostracods

MF4: $P / G$ with crinoids

MF5: $P / G$ with peloids and algae

MF6: $G$ with crinoids and peloids

MF7: $G$ with crinoids, lithoclasts and peloids

MF8: $G$ with peloids and ooids

Figure 6. Sedimentological model and microfacies from the Belgian Tournaisian. Scale bar: $1 \mathrm{~mm}$.

Landelies formations, is rich in peloids together with various bioclasts of mixed open-marine (crinoids, brachiopods, trilobites) and proximal character (palaeosiphonocladales, Girvanella). The origin of peloids can be diverse: faecal, micritized grains, direct algal origin, and intraclasts (Tucker \& Wright 1990). Even if the micritization of bioclasts is proven by local preservation of relics within larger peloids, other origins cannot be excluded. Some grainstone levels within MF5 can be interpreted as proximal tempestites (Aigner \& Reineck 1982). This corresponds in fact to the amalgamation of storm deposits with erosion of the major part of a classical storm sequence, leading to the preservation and repetition of truncated sequences (Van Steenwinkel 1980, 1988).

The transition to the inner ramp is observed with MF6, frequent in the Hastière and Landelies formations. This facies is dominated by transported peloids and crinoids mixed with some algae. Many of the grains are micritized and most of the peloids originate from completely micritized grains. Relatively good sorting and grainstone texture suggest a location above the fair weather wave base. MF7, observed in the Landelies Formation, is relatively similar to MF6, with a higher percentage of micritized grains. High micritization indicates a longer exposure of bioclasts to wave action and biodegradation before burial. Large lithoclasts are probably reworked from algal-microbial mats or from fine-grained sediments deposited in pools in littoral setting (Tucker \& Wright 1990, Préat \& Kasimi 1995). MF8 is observed only at the base of the Hastière Formation, in the Gendron section. This highly micritized ooid and peloid-rich microfacies probably corresponds to tidal channels in a littoral environment (Loreau \& Purser 1973). Fig. 6 shows the bathymetric distribution of microfacies along the Burchette \& Wright (1992) carbonate ramp model.

\section{Sedimentary evolution and sequence stratigraphy}

The sequence stratigraphic canvas used in the present study is based on the studies by Hance et al. (2001), Devuyst et al. (2005) and Poty et al. (2006, 2011), who defined four third-order sequences in the Tournaisian. The first of these corresponds to the Comblain-au-Pont Formation and the first two members of the Hastière Formation (TST1-HST1). In the Rivage section (Fig. 7), facies are dominated by MF6 and 7 (inner ramp). In the Gendron section, the first beds of the Hastière Formation record MF8 and MF2, passing upwards to MF5, MF6 and MF7, typical of mid- and inner ramp settings.

The second sequence starts with the upper member of the Hastière Formation, and includes the Pont d'Arcole 
and Landelies formations. The last member of the Hastière Formation is characterized by a deepening event (MF6-5-4-3-2), which is relatively progressive in Gendron but more rapid in Rivage. The bulk of the Pont d'Arcole Formation (TST2) accumulated on an outer ramp (MF1-MF3) while the Landelies Formation (HST2-FSST2) ( $c f$. Plint \& Nummedal 2000) shows a progressive shallowing upwards from an outer to an inner ramp (MF3-MF7).

The third sequence encompasses the Yvoir and the Ourthe formations in the CSA and the Maurenne, Bayard and Waulsort (partim) formations in the DSA. The Yvoir Formation (TST3) was deposited on a mid ramp (MF4-MF6) while the Maurenne Formation (LST3) corresponds to a protected area on a mid or inner ramp (MF2). The Ourthe Formation, a thick crinoidal unit (MF4), is deposited on a mid-ramp (HST3-FSST3?). The crinoidrich Bayard Formation (MF6-MF4) and the lower part of a Waulsortian mound (MF3) are related to the TST3-HST3-FSST3.

The fourth sequence (TST4) starts with a recurrence of the Bayard Formation in Gendron and with the Martinrive Formation (MF4-MF3) in the CSA.

A comparison of microfacies through all the sections correlated by biostratigraphy and sequence stratigraphy (Fig. 7) highlights the shallower character of the Rivage section when compared with the Gendron section. This is especially true for the Hastière Formation, dominated by MF7 in Rivage and by MF6 in Gendron.

\section{Magnetic susceptibility}

MS values for Rivage and Gendron range from near zero to $14 \times 10^{-8} \mathrm{~m}^{3} / \mathrm{kg}$. These relatively low MS values are consistent with published values from Frasnian platform limestone (between 0 and $32 \times 10^{-8} \mathrm{~m}^{3} / \mathrm{kg}$ : Da Silva \& Boulvain 2002), Eifelian ramp argillaceous limestone (from -2 to 12 $\times 10^{-8} \mathrm{~m}^{3} / \mathrm{kg}$ : Mabille \& Boulvain 2007), or Givetian platform limestone ( -1 to $43 \times 10^{-8} \mathrm{~m}^{3} / \mathrm{kg}$ : Boulvain et al. 2010; Fig. 8).

When comparing the MS values of the two sections, similar trends and events are observed (Fig. 7). These are considered as isochronous and correlatable (see Ellwood et al. 1999). The MS curves will now be shortly described, in relation to the sequence stratigraphy units previously defined by Hance et al. (2001) and Poty et al. (2006, 2011).

TST1 is characterized by a progressive lowering of MS values (from $10 \times 10^{-8} \mathrm{~m}^{3} / \mathrm{kg}$ to $2 \times 10^{-8} \mathrm{~m}^{3} / \mathrm{kg}$ ) in Rivage and oscillations between these values in Gendron. HST shows very low MS values in Rivage and a rapid decrease in Gendron. In both sections, TST2 shows a significant MS increase up to $10 \times 10^{-8} \mathrm{~m}^{3} / \mathrm{kg}$ followed by oscillating values between $8 \times 10^{-8} \mathrm{~m}^{3} / \mathrm{kg}$ and $12 \times 10^{-8} \mathrm{~m}^{3} / \mathrm{kg}$.
Again, HST2-FSST2 shows decreasing values, from $14 \times 10^{-8} \mathrm{~m}^{3} / \mathrm{kg}$ to 0 or slightly negative values. Higher MS values (around $12 \times 10^{-8} \mathrm{~m}^{3} / \mathrm{kg}$ ) for LST3 are observed in Gendron but not in Rivage. TST3-HST3-FSST3 is characterized again by low MS values and finally, TST4 shows slightly higher MS values $\left(4 \times 10^{-8} \mathrm{~m}^{3} / \mathrm{kg}\right)$.

\section{Discussion}

The relationships between the MS signal and different sedimentological characteristics of the two sections will now be addressed: these characteristics include lithostratigraphic units, lithology, sequence stratigraphic units and facies. Fig. 9 represents the mean MS values for each formation in Rivage and Gendron. Some formations are represented in both sections (Hastière, Pont d'Arcole, Landelies) while others are observed only in one section (Yvoir, Maurenne, Ourthe, Bayard, Waulsort, Martinrive) because the paleogeographic differentiation between CSA and DSA was increasing during the Tournaisian (Poty 1997). A first observation is that mean MS values decreased through time, except for the shaly Pont d'Arcole Formation. This could indicate a progressive long-term lowering of the MS carrier input into the basin. Actually, a parallel decrease of the detrital input is also visible by a reduction in the number and thickness of the argillaceous beds from the Hastière Formation to the upper Tournaisian. Another interesting observation is that the Gendron formations show systematically higher MS values than the Rivage ones. Following the same interpretation, this suggests a higher MS-carrier input in Gendron than in Rivage. As stated previously, detrital silt and sand-sized quartz is also more abundant in Gendron than in Rivage.

It is interesting to note that magnetite was extracted from shale of the Pont d'Arcole Formation using a permanent magnet (confirmed by X-ray diffraction). A relatively high proportion of magnetite suggests that the MS signal is dominated by the ferromagnetic minerals, as already proposed by Devleeschouwer et al. (2010).

As previously stated, the Hastière and Landelies formations are characterized by alternations of limestone and subordinate shale beds (Conil \& Vandenven 1972). This common pattern could be the result of cyclic variations in carbonate productivity or detrital input or even could be a diagenetic effect, by concentration of argillaceous residue by pressure solution (Wanless 1979). Fig. 10 shows that, for a series of limestone and shale beds of the Hastière and Pont d'Arcole formations in Gendron, MS values remain relatively close. This simple observation allows the dismissal of the last hypothesis for the development of the argillaceous beds: if these beds were of diagenetic origin, MS carriers would have been concentrated by pressure solution and shale beds would have 


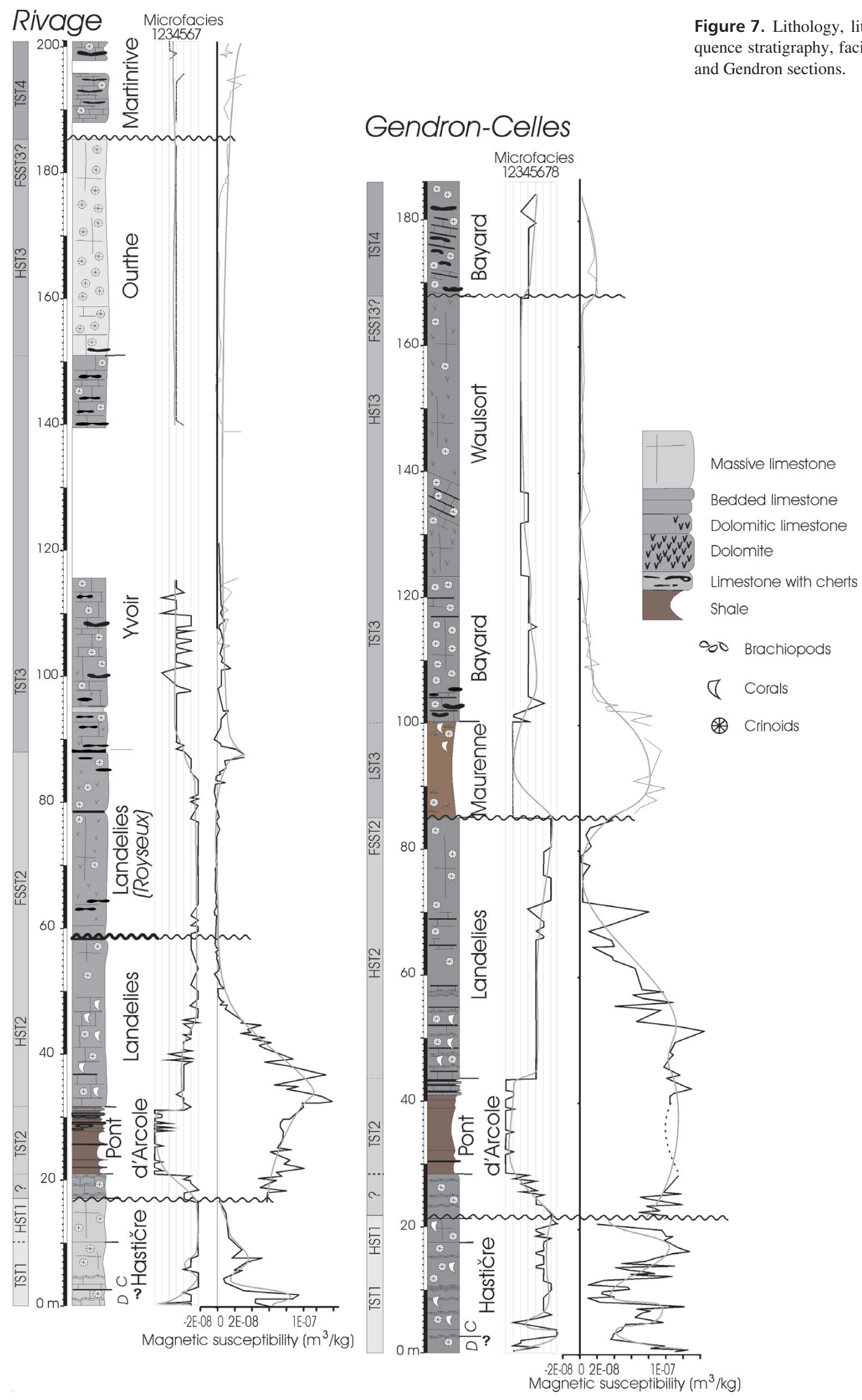




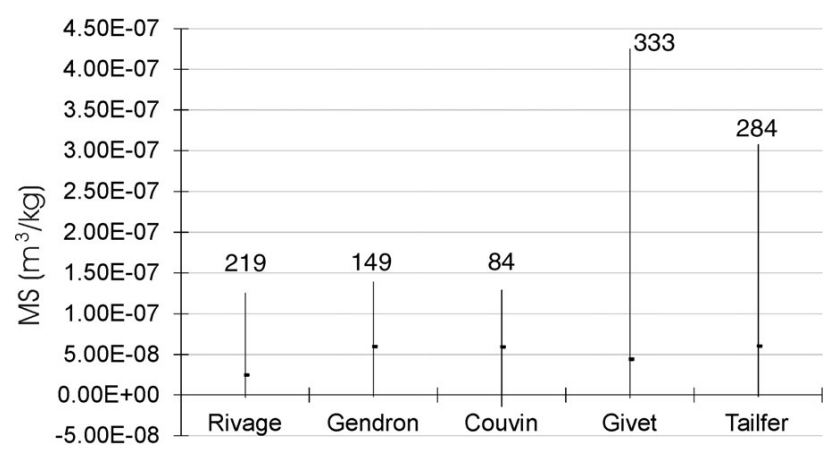

Figure 8. MS values (maximum, minimum, mean and number of samples) from different sections and platform types. Rivage and Gendron Tournaisian ramp (this paper); Couvin - Eifelian ramp (Mabille \& Boulvain 2007); Givet - Givetian platform (Boulvain et al. 2010); Tailfer - Frasnian platform (Da Silva \& Boulvain 2002).

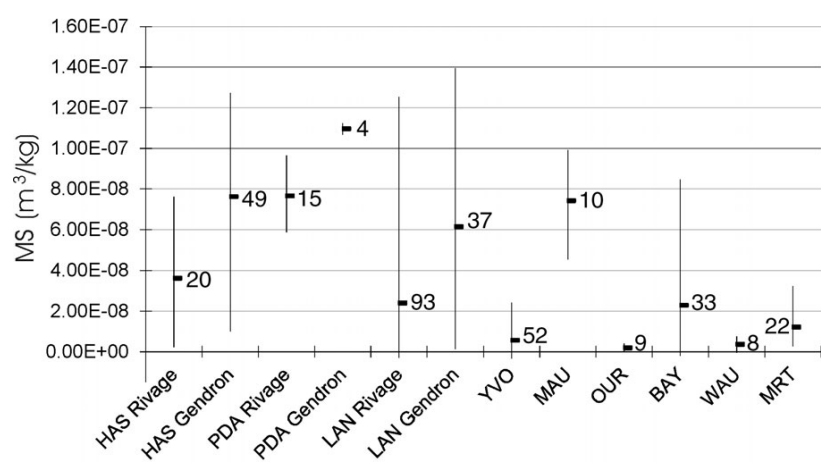

Figure 9. MS values (maximum, minimum, mean and number of samples) for the different formations of the Rivage and Gendron sections. Abbreviations: HAS - Hastière Fm.; PDA - Pont d'Arcole Fm.; LAN - Landelies Fm.; YVO - Yvoir Fm.; MAU - Maurenne Fm.; OUR - Ourthe Fm.; BAY - Bayard Fm.; WAU - Waulsort Fm.; MRT - Martinrive Fm.

higher MS values than their limestone counterparts. This result suggests also that the input of MS-carriers stayed roughly constant during the deposition of the limestoneshale alternation.

At a higher scale, the MS-systems tracts relationships highlighted in this study are relatively consistent and in agreement with the Crick et al. (1994) model (Fig. 7): LST show high values while TST are characterized by decreasing values and HST-FSST by the lowest values (excepted for the base of the Landelies Formation). This corresponds to the tendencies previously observed on the Belgian Frasnian platform where one HST shows low MS values (mean of $2 \times 10^{-8} \mathrm{~m}^{3} / \mathrm{kg}$ ) and the next TST shows higher values (mean of $6.6 \times 10^{-8} \mathrm{~m}^{3} / \mathrm{kg}$ ) (Da Silva \& Boulvain 2006). As already proposed by different authors, the results presented here point to an MS signal probably dominated by lithogenic inputs (Crick et al. 1997, 2001; Ellwood et al. 2000; Hladil 2002). The proportion of lithogenic inputs seems to be higher during low sea level, when larger portion of continental areas are exposed. During low sea level, the base level is lowered and heightened erosion increases the detrital contribution into the marine system. This material is then dispersed by bottom currents throughout ocean basins and the MS of the sediments increases accordingly. This hypothesis is that most commonly cited to explain MS variations (Borradaile et al. 1993, Robinson 1993, English 1999, Ellwood et al. 2000, Stage 2001). Other mechanisms, also related to sea level change, can be responsible for increase of magnetic materials in sedimentary basins during lowering sea level. As suggested by Tite \& Linington (1975) for example, pedogenesis can be an important source of magnetite during emersion of internal zones of carbonate platforms. As already proposed by Mabille \& Boulvain (2007), the magnetic fraction seems to be hydrodynamically linked to the detrital sand and siltsize quartz fraction.

Regionally, these MS results confirm some recent improvements of the sequence stratigraphy framework. The high but decreasing MS values of the upper member of the Hastière Formation are consistent with a TST (Hance et al. 2001, Poty et al. 2011) rather than a LST (Devuyst et al. 2005). Moreover, the sharp contact between low and high MS values in the same formation argues for a sequence boundary with a well-developed erosion surface. Conversely, the lack of high MS values in the Rivage section at the beginning of sequence 3 leads us to question the presence of the LST3, well developed in Gendron. This could be related to the deeper setting of the Gendron section in the DSA, while the CSA was possibly emergent during deposition of LST3.

Available data in the literature (e.g. Hladil 2002, Da Silva \& Boulvain 2002) support the notion that, generally, proximal microfacies possess higher values of MS than distal ones. This is explained by the relative proximity to the terrestrial source. However, the average MS values of each microfacies in the present study (Fig. 11) show just the opposite trend, with higher MS values for distal microfacies and lower values for proximal ones. The very low mean MS value recorded by MF4 is probably related to the high crinoid content (diamagnetic calcite).

This inverse relationship was already highlighted by Zhang et al. (2000) for Tournaisian sections in China and by Bábek et al. (2010) for a series of sections around the Tournaisian-Viséan boundary in Ireland, England, Belgium and Germany as well as by Mabille \& Boulvain (2007) for a Belgian Eifelian-Givetian ramp section.

This variable MS-facies relationship led Da Silva et al. (2009a) to propose that the record of average MS along a proximal-distal profile differs depending on the platform type. Mean MS values increase towards the most proximal facies on carbonate platforms, whereas they increase towards the most distal facies of ramps. One hypothesis is that, with a constant and homogeneous detrital supply, the MS variations are mainly 
Figure 10. Comparison of MS values from limestone and adjacent shale beds for different samples from Hastière and Pon d'Arcole formations (Gendron section). G51-121: samples.

Figure 11. MS values (maximum, minimum, mean and number of samples) from the different facies (1-7).
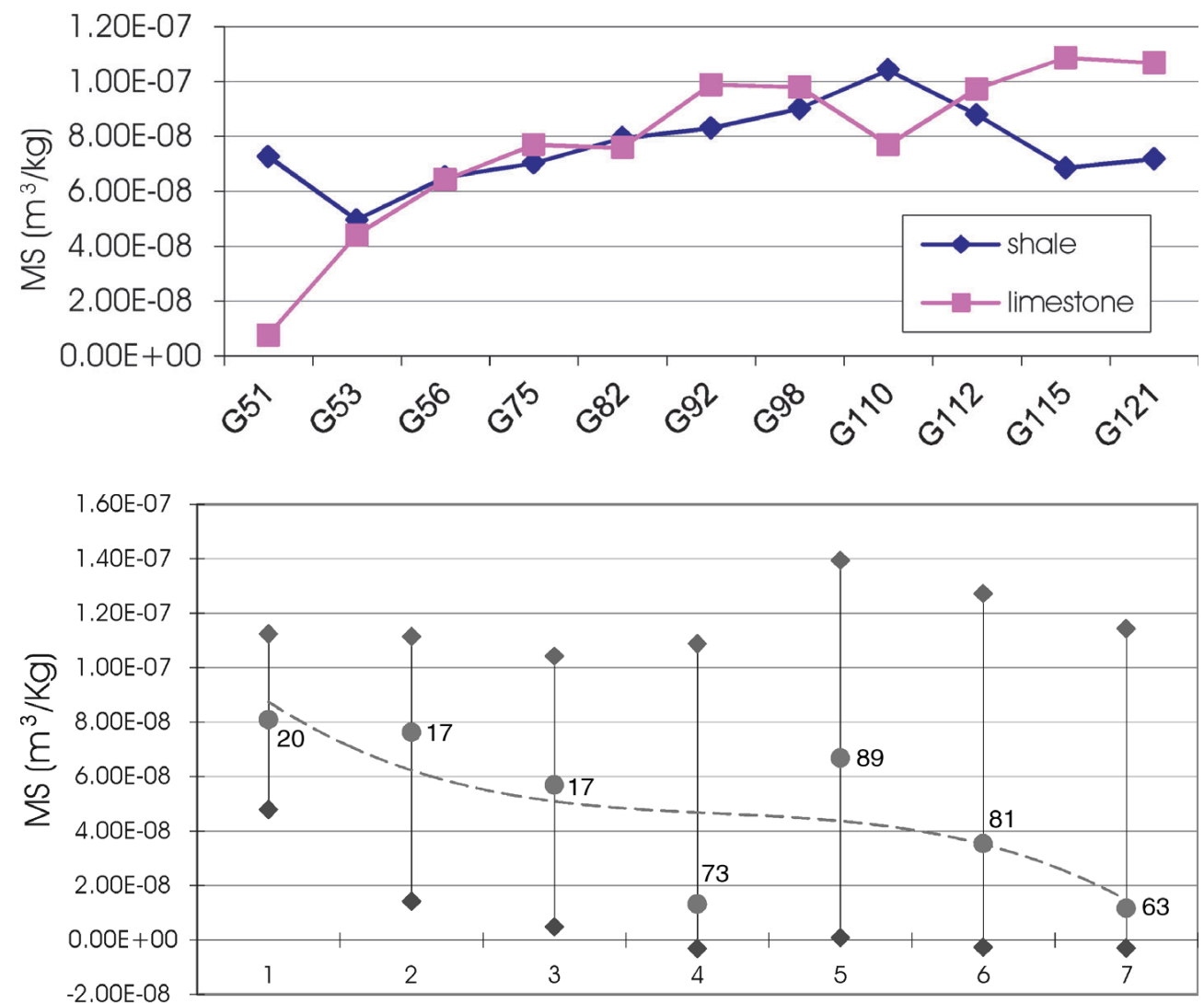

microfacies controlled by water agitation and carbonate productivity which are lower on outer than on inner ramp systems (Mabille \& Boulvain 2007, Da Silva et al. 2009a, Bábek et al. 2010). The present study on Tournaisian ramp deposits confirms this hypothesis. Another explanation proposed by Zhang et al. (2000) is that deeper environments tend to form reducing sediments, which promote the development of authigenic minerals like pyrrhotite and siderite. These minerals are paramagnetic and could result in higher MS values.

\section{Conclusions}

This sedimentological and MS study is dedicated to two important Belgian Tournaisian reference sections, the Rivage road and railway sections and the Gendron-Celles railway section. These sections belong to two different sedimentation areas; a shallow ramp for Rivage (CSA) and a subsiding area for Gendron (DSA). Both sections are characterized by a carbonate-dominated sedimentation (crinoids-peloidsalgae assemblages), interrupted by more argillaceous facies related to rapid sea-level rises (crinoids-brachiopodsbryozoans assemblages). Accommodation space was significantly higher in the DSA and allowed the development of Waulsortian buildups during the Ivorian.
MS curves allow better correlation of the two sections and are in agreement with the $3^{\text {rd }}$ order sequential interpretation. LST show the highest MS values while TST are characterized by decreasing values and HST-FSST by the lowest values. These results again suggest that the MS signal is probably dominated by lithogenic inputs (Crick et al. 1997, 2001; Ellwood et al. 2000; Hladil 2002) and controlled by magnetite (Devleeschouwer et al. 2010, Riquier et al. 2010). The proportion of lithogenic inputs seems to be higher during low sea level, when significant parts of continental area are exposed. During low sea level, the base level is lowered and heightened erosion increases the detrital contribution into the marine system. At the facies level, average MS values are higher for distal microfacies and lower for proximal ones, suggesting that, with a constant and homogeneous detrital supply, the MS variations are mainly controlled by water agitation and carbonate productivity which are lower on outer than on inner ramp systems.

As a consequence, variations of MS seem to be related both to fluctuations in detrital input and oceanic parameters. MS evolution with palaeogeography can be integrated in the Da Silva et al. (2009a) model for the Devonian: external ramp settings show low carbonate productivity, low water agitation and high MS, whereas more proximal environments are characterized by higher carbonate productivity, higher water agitation and lower MS. 


\section{Acknowledgements}

The authors are very grateful to Tony Wright (University of Wollongong, Australia) for helpful comments and great linguistic help. Hans-Georg Herbig (Universität zu Köln) and George Sevastopulo (Trinity College Dublin) are warmly acknowledged for their high quality review. This paper is a contribution to the IGCP 580 "Application of magnetic susceptibility on Palaeozoic sedimentary rocks".

\section{References}

Aigner, T. 1985. Storm depositional systems. Lecture Notes in Earth Sciences 3, 1-174. DOI 10.1007/BFb0011412

Aigner, T. \& Reineck, H.-E. 1982. Proximality trends in modern storm sands from the Helgoland Bight (North Sea) and their implications for basin analysis. Senckenbergiana maritima 14, 183-215.

Bábek, O., Kalvoda, J., Aretz, M., Cossey, P.J., Devuyst, F.-X., Herbig, H.-G. \& Sevastopulo, G. 2010. The correlation potential of magnetic susceptibility and outcrop gammaray logs at Tournaisian-Viséan boundary sections in Western Europe. Geologica Belgica 13, "Magnetic susceptibility, correlations and Palaeozoic environments”, 291-308.

Borradaile, G.J., Chow, N. \& Werner, T. 1993. Magnetic hysteresis of limestones: facies control? Physics of the Earth and Planetary Interiors 76, 241-252. DOI 10.1016/0031-9201(93)90016-3

Boulvain, F., Mabille, C., Poulain, G. \& Da Silva, A.-C. 2010. A magnetic susceptibility curve for the Devonian Limestone from Belgium. Geologica Belgica 13, 113-117.

Burchette, T.P. \& Wright, V.P. 1992. Carbonate ramp depositional systems. Sedimentary Geology 79, 3-57. DOI 10.1016/0037-0738(92)90003-A

Conil, R. (coll. Lys, M. \& PAPROTH, E.) 1964. Localités et coupes types pour l'étude du Tournaisien inférieur (révision des limites sous l'aspect micropaléontologique. Académie royale de Belgique, Classe des Sciences, $2^{e}$ série 15, 1-105.

ConIL, R. 1968. Le calcaire carbonifère depuis le Tn1a jusqu'au V2a. Annales de la Société géologique de Belgique 90, 687-726.

Conil, R., Dreesen, R., Lentz, M.A., Lys, M. \& Plodowski, G. 1986. The Devono-Carboniferous transition in the FrancoBelgian basin with reference to foraminifera and brachiopods. Annales de la Société géologique de Belgique 109, 19-26.

Conil, R., Groessens, E. \& Pirlet, H. 1977. Nouvelle charte stratigraphique du Dinantien type de la Belgique. Annales de la Société Geologique du Nord 96, 363-371.

Conil, R., Groessens, E., Hibo, D., Laloux, M., Lees, A. \& Pоту, E. 1988. The Tournaisian-Viséan boundary in the type area. 145 pp. Guidebook, Field meeting Palaeontological Association Carboniferous Group. Institut de Géologie, Université Catholique de Louvain-la-Neuve.

Conil, R. \& VAndenven, G. 1972. Le Tournaisien des Sondages de Saint-Aubin, Chaumont et Silenrieux. Belgian Geological Survey Professional Paper 1, 1-23.

CRICK, R.E., Ellwood, B. \& El Hassani, A. 1994. Integration of biostratigraphy, magnetic susceptibility and relative sea-level change: A new look at high resolution correlation. Subcommission on Devonian Stratigraphy, Newsletter 11, 59-66.

Crick, R.E., Ellwood, B., El Hassani, A., Feist, R. \& Hladil, J. 1997. Magnetosusceptibility event and cyclostratigraphy (MSEC) of the Eifelian-Givetian GSSP and associated boundary sequences in north Africa and Europe. Episodes 20, $167-175$.

Crick, R.E., Ellwood, B., Hladil, J, El Hassani, A., Hrouda, F. \& CHLUPÁČ, I. 2001. Magnetostratigraphy susceptibility of the Př́idolian-Lochkovian (Silurian-Devonian) GSSP (Klonk, Czech Republic) and coeval sequence in Anti-Atlas Morocco. Palaeogeography, Palaeoclimatology, Palaeoecology 167, 73-100. DOI 10.1016/S0031-0182(00)00233-9

Da Silva, A.-C. \& Boulvain, F. 2002. Sedimentology, magnetic susceptibility and isotopes of a Middle Frasnian carbonate platform: Tailfer section, Belgium. Facies 46, 89-102. DOI 10.1007/BF02668075

Da Silva, A.-C. \& Boulvain, F. 2006. Upper Devonian carbonate platform correlations and sea level variations recorded in magnetic susceptibility. Palaeogeography, Palaeoclimatology, Palaeoecology 240, 373-388. DOI 10.1016/j.palaeo.2006.02.012

Da Silva, A.-C., Mabille, C. \& Boulvain, F. 2009a. Influence of sedimentary setting on the use of magnetic susceptibility: examples from the Devonian of Belgium. Sedimentology 56, 1292-1306. DOI 10.1111/j.1365-3091.2008.01034.x

Da Silva, A.-C., Potma, K., Weissenberger, J.A.W., Whalen, M.T., Humblet, M., Mabille, C. \& Boulvain, F. 2009b. Magnetic susceptibility evolution and sedimentary environments on carbonate platform sediments and atolls, comparison of the Frasnian from Belgium and Alberta, Canada. Sedimentary $G e$ ology 214, 3-18. DOI 10.1016/j.sedgeo.2008.01.010

DeVleEsChOUwer, X. 1999. La transition Frasnien-Famennien (Dévonien Supérieur) en Europe: Sédimentologie, stratigraphie séquentielle et susceptibilité magnétique. 411 pp. Unpublished Ph.D. thesis, Université Libre de Bruxelles.

Devleeschouwer, X., Petitclerc, E., Spassov, S. \& Préat, A. 2010. The Givetian boundary at Nismes parastratotype (Belgium): the magnetic susceptibility signal controlled by ferromagnetic minerals. Geologica Belgica 13, 351-366.

Devuyst, F.-X., Hance, L. \& Poty, E. 2005. The Dinantian of Southern Belgium revisited: sedimentary history and biostratigraphy. A guidebook of key sections. IUGS Subcommission on Carboniferous Stratigraphy field trip, May 2005, 1-79.

DuNHAM, R.J. 1962. Classification of carbonate rocks according to depositional texture, 108-121. In HAM, W.E. (ed.) Classification of carbonate rocks. American Association of Petroleum Geologists Bulletin 87.

Ellwood, B.B., Crick, R.E. \& El Hassani, A. 1999. Magnetosusceptibility event and cyclostratigraphy (MSEC) method used in geological correlation of Devonian rocks from AntiAtlas Morocco. American Association of Petroleum Geologists Bulletin 83, 1119-1134.

Ellwood, B.B., Crick, R.E., El Hassani, A., Benoist, S.L. \& YounG, R.H. 2000. Magnetosusceptibility event and cyclostratigraphy method applied to marine rocks: detrital input versus carbonate productivity. Geology 28, 1135-1138. DOI 10.1130/0091-7613(2000)28<1135:MEACMA>2.0.CO;2 
ENGLISH, L.T.P. 1999. The use of magnetic susceptibility and trace element geochemistry for the correlation of fine-grained siliciclastic sequences: a Late Llandovery example from northwest England. Geological Magazine 136, 423-436. DOI 10.1017/S0016756899002587

Fielitz, W. \& Mansy, J.L. 1999. Pre- and synorogenic burial metamorphism in the Ardenne and neighbouring areas (Rhenohercynian zone, central European Variscides). Tectonophysics 309, 227-256.

DOI 10.1016/S0040-1951(99)00141-9

FLÜGEL, E. 2004. Microfacies of carbonate rocks. 976 pp. Springer-Verlag, Berlin.

Groessens, E. 1975. Distribution de conodontes dans le Dinantien de la Belgique. International Symposium on Belgian Micropaleontological limits, from Emsian to Viséan 17, $1-193$.

Guillocheau, F. \& Hoffert, M. 1988. Zonation des tempêtes en milieu de plate-forme: le modèle des plates-formes nordgondwanienne et armoricaine à l'Ordovicien et au Dévonien. Comptes-Rendus de l'Académie des Sciences de Paris 307(2), 1909-1916.

Hance, L., Poty, E. \& Devuyst, F.-X. 2001. Stratigraphie séquentielle du Dinantien type (Belgique) et corrélation avec le nord de la France (Boulonnais, Avesnois). Bulletin de la Société Géologique de France 172(4), 411-426. DOI 10.2113/172.4.411

Herbig, H.-G. \& Weber, H.M. 1996. Facies and stromatoporoid biostromes in the Strunian (latest Devonian) of the Aachen region (Germany), 359-364. In Reitner, J., Neuweiler, F. \& Gunkel, F. (eds) Global and Regional Controls on Biogenic Sedimentation. I. Reef Evolution. Göttinger Arbeiten zur Geologie und Paläontologie 2.

HLADIL, J. 2002. Geophysical records of dispersed weathering products on the Frasnian carbonate platform and early Famennian ramps in Moravia, Czech Republic: proxies for eustasy and palaeoclimate. Palaeogeography, Palaeoclimatology, Palaeoecology 181, 213-250.

DOI 10.1016/S0031-0182(01)00480-1

Hladil, J., Č́tchan, P., BÁBeK, O., Koptíková, L., Navrátil, T. $\&$ KubinOvá, P. 2010. Dust - A geology-orientated attempt to reappraise the natural components, amounts, inputs to sediment, and importance for correlation purposes. Geologica Belgica 13, "Magnetic susceptibility, correlations and Palaeozoic environments", 367-384.

Hladil, J., Geršl, M., Strnad, L., Frána, J., Langrová, A. \& SPIŠIAK, J. 2006. Stratigraphic variation of complex impurities in platform limestones and possible significance of atmospheric dust: a study with emphasis on gamma-ray spectrometry and magnetic susceptibility outcrop logging (Eifelian-Frasnian, Moravia, Czech Republic). International Journal of Earth Sciences 95, 703-723.

DOI 10.1007/s00531-005-0052-8

LEES, A. 1997. Biostratigraphy, sedimentology and palaeobathymetry of Waulsortian buildups and peri-Waulsortian rocks during the late Tournaisian regression, Dinant area, Belgium. Geological Journal 32, 1-36.

DOI 10.1002/(SICI)1099-1034(199703)32:1<1::AID-GJ715 $>3.0 . \mathrm{CO} ; 2-0$

LeEs, A., Hallet, V. \& HiBo, D. 1985. Facies variation in Waul- sortian buildups. Part I. A model from Belgium. Geological Journal 20, 138-153.

Loreau, J.P. \& Purser, B.H. 1973. Distribution and ultrastructure of Holocene ooids in the Persian Gulf, 279-328. In Purser, B.H. (ed.) The Persian Gulf. Springer-Verlag, Berlin.

Mabille, C. \& Boulvain, F. 2007. Sedimentology and magnetic susceptibility of the Upper Eifelian - Lower Givetian (Middle Devonian) in southwestern Belgium: insights into carbonate platform initiation, 109-124. In Álvaro, J.J., Aretz, M., Boulvain, F., Munnecke, A., Vachard, D. \& Vennin, E. (eds) Palaeozoic Reefs and Bioaccumulations: Climatic and Evolutionary Controls. Geological Society of London, Special Publications 275.

McCABe, C. \& ElmoRe, R.D. 1989. The occurence and origin of late Paleozoic remagnetizations in the sedimentary rocks of North Ameria. Review Geophysics 27, 471-494.

DOI 10.1029/RG027i004p00471

Paproth, E., Conil, R., Bless, M., Boonen, P., Bouckeart, J., Carpentier, N., Coen, M., Delcambre, B., Deprijck, C., Deuzon, S., Dreesen, R., Groessens, E., Hance, L., Hennebert, M., Hibo, D., Hahn, G., Hislaire, O., Kasig, W., Laloux, M., Lauwers, A., Lees, A., Lys, M., Op de Beek, K., Overlau, P., Pirlet, H., Poty, E., Ramsbottom, W., Streel, M., Swennen, R., Thorez, J., Vanguestaine, M., Van Steenwinkel, M. \& VIESLET, J.L. 1983. Bio- and lithostratigraphic subdivisions of the Dinantian in Belgium. A review. Annales de la Société Géologique de Belgique 106, 185-239.

Plint, A.G. \& Nummedal, D. 2000. The falling stage system tract: recognition and importance in sequence stratigraphic analyses, 1-17. In Hunt, D. \& Gawthorpe, R.C. (eds) Sedimentary responses to forced regressions. Geological Society, London, Special Publication 172.

Pоту, E. 1985. A rugose coral biozonation for the Dinantian of Belgium as a basis for a coral biozonation of the Dinantian of Eurasia. Compte-rendu Xième Congrès International de Stratigraphie et de Géologie du Carbonifère, Madrid 1983, 4, 29-31.

Pоту, E. 1997. Devonian and Carboniferous tectonics in the eastern and southern parts of the Brabant Massif (Belgium). Aardkundige Mededelingen K. U. Leuven 8, 143-144.

Poty, E., Aretz, M. \& Denayer, J. 2011. Uppermost Devonian and Lower Carboniferous of Southern Belgium. $11^{\text {th }}$ International Symposium on Fossil Cnidaria and Porifera, Liège, Fieldtrip 3. Kölner Forum Geologie Paläontologie 20, 99-150.

Poty, E., Devuyst, F.X. \& Hance, L. 2006. Upper Devonian and Mississippian foraminiferal and rugose coral zonations of Belgium and Northern France: a tool for Eurasian correlations. Geological Magazine 143, 829-857. DOI 10.1017/S0016756806002457

Poty, E., Hance, L., Lees, A. \& Hennebert, M. 2001. Dinantian lithostratigraphic units (Belgium). Geologica Belgica 4, 69-94.

PréAt, A. \& Kasimi, R. 1995. Sédimentation de rampe mixte silico-carbonatée des couches de transition eifeliennesgivetiennes franco-belges. Première partie: microfaciès et modèle sédimentaire. Bulletin des Centres Recherche Exploration-Production Elf Aquitaine 19, 329-375. 
READ, J.F. 1985. Carbonate platform facies models. American Association of Petroleum Geologists Bulletin 69, 1-21.

REINECK, H.E. \& Singh, I.B. 1972. Genesis of laminated sands and graded rythmites in storm-sand layers of shelf mud. Sedimentology 18, 123-128.

DOI 10.1111/j.1365-3091.1972.tb00007.x

Riquier, L., Averbuch, O., Devleeschoumer, X. \& TriboVILLARD, N. 2010. Diagenetic versus detrital origin of the magnetic susceptibility variations in some carbonate FrasnianFamennian boundary sections from Northern Africa and Western Europe: implications for paleoenvironmental reconstructions. International Journal of Earth Sciences 99, S57-S73. DOI 10.1007/s00531-009-0492-7

RoBINSON, S.G. 1993. Lithostratigraphic applications for magnetic susceptibility logging of deep-sea sediment cores: examples from ODP Leg 115, 65-98. In HaILwood, E.A. \& KidD, R.B. (eds) High Resolution Stratigraphy. Geological Society of London, Special Publication 70.

RochetTe, P. 1987. Metamorphic control of the magnetic mineralogy of black shales in the Swiss Alps: toward the use of "magnetic isogrades". Earth \& Planetary Sciences Letters 84, 446-456. DOI 10.1016/0012-821X(87)90009-4

SePkoski, J.J. JR., BAMBACH, R.K. \& Droser, M.L. 1991. Secular changes in Phanerozoic event bedding and biological overprint, 298-312. In Einsele, G., Ricken, W. \& Seilacher, A. (eds) Cycles and events in stratigraphy. Springer, Berlin.

Stage, M. 2001. Magnetic susceptibility as carrier of a climatic signal in chalk. Earth \& Planetary Science Letters 188, 17-27. DOI 10.1016/S0012-821X(01)00304-1
Tite, M.S. \& Linington, R.E. 1975. Effect of climate on the magnetic susceptibility of soils. Nature 256, 565-566.

DOI 10.1038/256565a0

TuCKer, M.E. \& Wright, V.P. 1990. Carbonate sedimentology. 482 pp. Blackwell, London. DOI 10.1002/9781444314175

VAN StEENWINKEL, M. 1980. Sedimentation and conodont stratigraphy of the Hastière Limestone, Lowermost Dinantian, Anseremme, Belgium. Mededelingen Rijks Geologische Dienst $32,30-33$.

Van Steenwinkel, M. 1988. The sedimentary history of the Dinant platform during the Devonian-Carboniferous transition. 173 pp. Ph.D. thesis, K.U. Leuven.

Van Steenwinkel, M. 1993. The Devonian-Carboniferous boundary in Southern Belgium: biostratigraphic identification criteria of sequence boundaries. Special Publications International Association of Sedimentologists 18, 237-246.

WaNLESS, H.R. 1979. Limestone responses to stress: pressure solution and dolomitization. Journal of Sedimentary Petrology 49, 437-462.

Zegers, T.E., Dekkers, M.J. \& BAily, S. 2003. Late Carboniferous to Permian remagnetization of Devonian limestones in the Ardennes: Role of temperature, fluids, and deformation. Journal of Geophysical Research 108, 1-19.

DOI 10.1029/2002JB002213

Zhang, S.H., WANG, X.L. \& ZhU, H. 2000. Magnetic susceptibility variations of carbonates controlled by sea-level changes Examples in Devonian to Carboniferous strata in southern Guizhou Province, China. Science in China, Series D - Earth Sciences 43, 266-276. 